\title{
Dilemmas of Sheltered Employment in Poland and Greece and the Concept of Supported Employment
}

\author{
Dorota Kobus-Ostrowska (iD) https://orcid.org/0000-0001-5004-6478 \\ Ph.D., University of Lodz, Faculty of Economics and Sociology \\ Department of Institutional Economics and Microeconomics, Lodz, Poland \\ e-mail: dorota.ostrowska@uni.lodz.pl
}

\section{Doxa Papakonstantinou (iD https://orcid.org/0000-0002-3242-7629 Assistant Professor, University of Macedonia, Department of Educational and Social Policy, Thessaloniki, Greece, e-mail: klerip@uom.gr}

\begin{abstract}
People with severe disabilities, such as severe mental disabilities and autism spectrum disorders, do not participate in the open, competitive labor market to the same extent as people without disabilities or other forms of disability. Sheltered employment is an internationally accepted approach for the vocational integration of people with severe disabilities, which introduces integration in sheltered workplaces mainly with other people with disabilities and ongoing support from the Government or self-government. Therefore, sheltered employment can be defined as the employment of a person with a disability under particular conditions. This paper presents the legislative framework regarding sheltered employment in Poland and Greece and the ways sheltered employment takes place in each of the two countries with the corresponding comparisons and conclusions. The results show a need for a more precise and more comprehensive legislative framework on sheltered employment in Poland and Greece. Alternative options for the vocational integration of people with severe forms of disabilities, such as supported employment programs, need to come to the fore. Supported employment seems to be the only effective and efficient way for people who have particular difficulties in finding and keeping a paid job in the open labor market to take up paid employment on an equal basis with other people. Does the concept of supported employment have a chance to prove itself on Poland and Greece's open labor markets and become a complementary tool in the vocational activation of people with disabilities? Legislative regulations, system projects, and stable sources of financing are necessary for both countries.
\end{abstract}


Keywords: sheltered employment, supported employment, disabilities, Poland, Greece

JEL: I3, I310, J8, J880

\section{Introduction}

People with severe disabilities do not participate in the labor market to the same extent as people without disabilities, which signifies the loss of valuable human resources and entails a significant burden on the national economy (Wehman et al. 2018, pp. 131-144). There are a variety of approaches to integrating people with severe forms of disability, such as supported and sheltered employment programs (Burns, White, and Catty 2008, pp. 498-502; Tsang et al. 2009, pp. 292-305). Sheltered employment refers to employment that takes place in facilities where most people have disabilities, with ongoing support and supervision of their work (Metzel et al. 2007, pp. 149-160). According to the international literature, sheltered employment mainly concerns individuals with autistic spectrum disorders and mental disabilities (García-Villamisar, Wehman, and Diaz Navarro 2002, pp. 309-312; Cimera et al. 2011, pp. 87-94; Akkerman et al. 2016, pp. 205-216) with the aim of teaching skills and preparing them for their future integration into the competitive labor market (Cimera et al. 2011, pp. 8794). Therefore, protection is provided only to those who, due to their disability, are unable to meet the expected standards. Thus, it is necessary to recognize the performance deficit and - compared to work in competitive conditions - create an appropriate sheltered zone for these people (Paszkowicz 2013, p. 38). In view of the above, the protection of an employed person may relate to various aspects of their professional work, at least because the working conditions will be different for a person who is blind, who is deaf, or who has a mobility disability.

Sheltered employment, therefore, offers people with severe disabilities skills training, pre-occupational services, group placements, and leisure and recreational activities - measures that are considered the first step in the process of their vocational rehabilitation (Cimera et al. 2011, pp. 87-94). This paper presents the framework of sheltered employment in Poland and Greece, and provides recommendations for improvement. As state-members of the European Union (EU), the paper discusses the national context of the two countries, affected at different levels by the economic crisis (Osinska and Kluth 2010, pp. 139-156; Lament 2017, pp. 5-16), but sharing many aspects a shared vision on the labor solidarity actions towards unemployment (Karakioulafi et al. 2020). The choice of the countries was based on the specific research interests of the authors. There is limited research on sheltered employment in European Union member states and scarce research in Poland and Greece. The current research adds up-to-date and combined data on two EU countries. The study aims to provide answers to the following research questions: a) What is the legislative framework re- 
garding sheltered employment in Poland and Greece, and in what ways is it realized in each of the two countries? Furthermore, b) What is the critical appraisal of the existing framework for the two countries?

\section{Methodology}

The methodology was based on the review strategy chosen by Ebuenyi et al. (2019, pp. 99-105). Using electronic databases like Nomotelia, the authors reviewed Poland and Greece's laws and policies on sheltered employment and, generally, on the employment of people with severe disabilities. The authors reviewed the full content of the laws and policies retrieved, individually and in cooperation, to solve any disagreement and decide on the search results. The Medline, Emerald, and Google Scholar databases were used to obtain research data on the evaluation of sheltered employment policies.

\section{Sheltered employment in Poland}

In Poland, the rate of self-reported long-standing limitations due to health issues in 2019 was $24.4 \%$, close to the $24 \%$ rate of the European Union-27 member states (Eurostat 2019). In Poland, the legal framework for sheltered employment is governed by the Act of 27 August 1997 on Vocational and Social Rehabilitation and Employment of Persons with Disabilities (Act of 27 August 1997) and the Regulation of the Minister of Labor and Social Policy of 19 December 2007 regarding the Company Fund for the Rehabilitation of the Disabled (Regulation of the Polish Minister of Labor and Social Policy of 19 December 2007). Protected employment of persons with disabilities is carried out through Vocational Activity Workshops (ZAZs) and Sheltered Workshops (ZPChs), among others. Specific requirements are provided for each form. And so, for example, ZAZs may be formed by poviat, commune, foundation, association, and other social organizations whose statutory tasks include the professional and social rehabilitation of disabled people and co-financing from the State Fund for the Rehabilitation of Disabled People (PFRON) funds. In turn, employers may apply for Sheltered Workshop (ZPCh) status if they meet certain conditions and to whom the Voivode will grant PFRON funds from the subsidy transferred to the local self-government.

Vocational Activity Workshops are, therefore, organizations that operate on a non-profit basis, subject to the laws of economics, and fighting for market position, customers, markets, and funds for further functioning (Stevens and Martin 1999, pp. 19-29). As of 31 December 2019, there were only 126 ZAZs in Poland; by comparison, at the end of 2016, only 103 such entities were operating (Biuro Pełnomocnika Rządu do Spraw Osób Niepełnosprawnych n.d.). The total employment amounted to 7197 people, including 5492 disabled people in Vocational Activity Workshops (Biuro Pełnomocnika Rządu do Spraw Osób Niepełnosprawnych n.d.). 
One of the conditions for the operation of a ZAZ is that at least $70 \%$ of the total number of employees are people with mild and moderate disabilities. In Poland, the employment rate of disabled people in ZAZs in 2016-2019 met the statutory requirement and was between $72 \%$ and $76.3 \%$ (in 2019).

In turn, the status of Sheltered Workshop can be obtained by employers if they have been running a business for at least 12 months and employ a minimum of 25 full-time employees. In addition, employees with disabilities should account for at least 50\% of all employees, of which at least $20 \%$ have a severe or moderate disability. Exceptionally, employers can employ $30 \%$ of people with disabilities if they meet a very strict provision. Namely, employers must prove that employees have a moderate or severe disability and are blind, mentally ill, or mentally disabled (Act of 27 August 1997 - articles 28, 30, 31 and 33; Regulation of the Minister of Labor and Social Policy of 19 December 2007).

Currently, Poland is experiencing a slow death of the protected labor market, which should by its very nature be a market subject to "special protection." This phenomenon is even more pronounced because over the past two decades, no significant changes have been introduced to facilitate the transition of people from the protected market to the open labor market. All initiatives only made the situation worse. For example, sheltered workshops (Barczyński 2013) were the main beneficiaries of the system for supporting disabled people by subsidizing the remuneration of disabled employees. The reduction of wage subsidies for employees in ZPChs has made it inefficient (taking into account the profitability of the business) to employ disabled people on the protected market. If we also take into account the fact that the overriding goal of this business was and still is to maximize the benefits of owners and shareholders, then it should not come as a surprise that since subsidies to the remuneration of employees of ZPChs were reduced (equating them with subsidies for entrepreneurs in the open labor market), these businesses have been operating on the edge of economic profitability for many years. This is also confirmed by the systematically decreasing number of sheltered workshops, from 2,463 in 2004, to 1,091 in 2016, and only 867 entities at the end of December 2019. And although the total employment in ZPChs was 138,483 people, only 107,903 were people with disabilities. Thus, the share of people with disabilities in total employment in professional activity facilities met the statutory requirement, amounting to $77.9 \%$.

\section{Sheltered employment in Greece}

In Greece, the rate of self-reported long-standing limitations due to health issues in 2019 was 23.1\%, one unit lower than the EU-27 average (Eurostat 2019). Recent data on the rates of people with disabilities involved in sheltered workshops are not available, as there is no official record. However, the labor market policies' cost rates are an indication, particularly for the active labor market policies and sheltered/supported employ- 
ment for 2016, which was zero (Eurostat 2018). In Greece, the legislative framework for sheltered employment regulates the operation of the Protected Productive Laboratories (PPLs), which are enshrined in article 17 of Law 2646/1998 'Development of the National Social Care System and other provisions' (OGG A' 236). In particular, it is stipulated that legal entities governed by public law and supervised by the Ministry of Health, as well as private sector, non-profit, and specially certified entities, may operate as PPLs, provided that they carry out activities involving people with mental disabilities, or severe physical and multiple disabilities (par. 2, art. 17, Law 2646/1998).

PPLs operate under specific programs on intellectual disability, autism spectrum disorders, and severe mental, physical, and multiple disabilities within the National Program for People with Disabilities (par. 1, art. 17, Law 2646/1998), the purpose of which is to ensure that these people are able to participate equally in social life, in the productive and employment process in the open labor market, or in alternative forms of employment, as well as in the creation of the conditions for independent or semi-autonomous living (par. 1, art. 17, Law 2646/1998). Indicative workshops that operate in PPLs include gardening-floriculture workshops, handmade leather bookbinding, candle making, cooking, graphic arts and informatics, computers, jewelry and accessories, and crafts and pottery workshops (Vocational Rehabilitation Center for Persons with Disabilities n.d.; Cerebral Palsy Greece/Open Door n.d.).

It is specified in Law 2646/1998 that three-fifths (3/5) of the employees in PPLs must have the above-mentioned disabilities. They must have a minimum age of 20 , and there is an additional condition that they must have completed a program of vocational training that lasted at least two years (par. 3, art. 17, Law 2646/1998). A Presidential Decree of the Ministers of Finance, Labor and Social Insurance, and Health (art. 17, par. 2, Law 2646/1998) sets the regulations on PPLs' legal form, organizational structure, operation, financing conditions, employment relationship, and calculation of their employees' wages, as well as the process of promoting their products. In practice, the lack of a clear and complete legislative framework on PPLs means they operate informally, mainly as parts of departments/care units for people with disabilities, supervised by the Ministry of Health and Social Solidarity, Non-Governmental Organizations, and Parents and Guardians Associations for people with severe and multiple disabilities (National Confederation of Persons with Disabilities 2007, p. 26).

Further strengthening of PPLs is regulated in the following legislative framework: a) Law 4412/2016 'Public Works, Supplies and Services Contracts (Adaptation to Directives 2014/24/EU and 2014/25/ EU)' (OGG A '147), in particular, Article 20 (Contracts awarded exclusively - Article 20 of Directive 2014/24/EU), and b) Law 4413/2016 'Award and execution of concession contracts - Harmonization with European Directive 2014/23/EU of the European Parliament and of the Council of 26 February 2014 on the award of concession contracts (OJ L 94/1/28-3-14) and other provisions' (OGG A' 148), in particular, Article 23 (Reserved Concessions - Article 24 of Directive 2014/23/EU). According to the above, PPLs are exclusively entitled to participate in: a) public procurement procedures (par. 1, art. 20, Law 4412/2016), and b) proce- 
dures for awarding service concession contracts (par. 1, art. 23, Law 4413/2016). Additionally, contracting authorities are allowed to provide for the execution of public contracts in the context of sheltered employment programs, provided that more than $30 \%$ of those employed are people with disabilities (par. 2, art. 20, Law 4412/2016, par. 1, art. 23, Law 4413/2016). The above regulations are intended to facilitate the vocational integration/reintegration of people with disabilities, and their introduction was considered necessary, as PPLs may not be able to contract under competition (Explanatory Report Law 4412/2016, p. 7).

\section{Conclusions}

The study aimed to present and critically appraise the legislative framework regarding sheltered employment in Poland and Greece. The social exclusion of people with disabilities has been the subject of discussions and disputes for many years around the world. Protected employment has been an important form of support that has been able to reduce social exclusion for people with disabilities for many years. Unfortunately, according to many, the effects of the proposed solutions, not only around the world (Damon 2012), but also in Poland (Garbat 2013, pp. 49-55; Barczyński 2016, pp. 69-73) and Greece, failed to live up to expectations (Burns, White, and Catty 2008, pp. 498-502).

The effectiveness of sheltered employment programs has often been criticized and questioned by researchers. Research on the effects of employing people with intellectual disabilities on their quality of life suggests that their quality is particularly higher when they are employed in the open labor market than in sheltered employment (Kober and Eggleton 2005, pp. 756-760). It is determined by the deeper sense of social inclusion but also by the autonomy and independence that result from employment in the open labor market. The question of the effects of sheltered employment on the quality of life of people with disabilities is also found in research on people with autism spectrum disorders, where it is argued that for them, sheltered employment does not lead to a substantial improvement in their quality of life compared to supported employment (García-Villamisar, Wehman, and Diaz Navarro 2002, pp. 309-312).

The results of a relevant study on the effectiveness of sheltered employment programs in people with autism spectrum disorders suggest that sheltered employment programs do not contribute to the expected improvement after their follow-up (Cimera et al. 2011, pp. 87-94). Employment rates do not rise when attending sheltered employment programs, and subsequently, the people involved have a significantly high cost of remaining in the labor market and low pay. The significant difference in the income of people with disabilities in sheltered employment compared to the corresponding higher income of people in supported employment was also confirmed in another study by Cimera (2017, pp. 108-120).

It is noted, however, that the effects of sheltered employment vary with the contribution of other factors, such as the type and the place of work, as these factors may 
make sheltered employment more economically advantageous in comparison to supported employment, depending on the case and the form of disability of the people involved in these programs (Wang, Lin, and Shu 2012, pp. 1672-1676; Cimera 2017, pp. 108-120). It is reported that the criticism of the effects of sheltered employment on people with intellectual disabilities relates to people with high levels of functional disability, as negative results are not confirmed for people with low levels of functionality (Kober and Eggleton 2005, pp. 756-760).

Although all activities undertaken within the framework of protected employment should result in employment with the employer, or self-employment, practice in Poland, for example, shows that people with disabilities or multiple disabilities either unsuccessfully look for a job for many years, or they remain in ZAZs or ZPChs. Although the legal framework clearly indicates that the ZAZ should give a person with disabilities the opportunity to acquire basic professional and life skills necessary in the workplace, while employment in the ZPCh should improve their professional skills and create the opportunity to enter the open labor market.

There are several important problems here. First, disabled people are increasingly dismissed from work, which is dictated by the reduction of employment related to the problems companies face due to COVID-19. Second, often due to worsening illnesses, people with disabilities who have worked in the open market for some time quit their job and look for a chance to return to the ZPCh or ZAZ. Third, if people with disabilities have been dismissed due to the company's temporary financial problems, or if they resigned due to deteriorating health and have not returned to the ZPCh or ZAZ, then they will fall out of the labor market and remain professionally inactive.

The criticism of sheltered employment programs has led the majority of people with disabilities, their relatives, and the vocational rehabilitation specialists to show their preference for supported over sheltered employment, both in Poland and in Greece. However, in practice, a large number of people with disabilities choose sheltered employment due to their concerns relating to work safety, transportation to and from work, long-term placement, convenient working hours, maintaining disability benefits, required skills jobs, and the social environment (Migliore et al. 2008, pp. 29-40). Therefore, the aim is to move people with disabilities into supported employment. In such cases, employment services should focus on: a) the issue of long-term employment of people with disabilities, b) reassuring the families of people with disabilities that their safety in the workplace in this respect would not be worse than in sheltered employment, and c) families and the social environment motivating and encouraging people with disabilities to search for and maintain employment (Migliore et al. 2008, pp. 29-40).

Supported employment is a solution that is intended to be a response to the challenges arising on the labor market for disabled job seekers and the economically inactive. Legislative work is still ongoing in Poland (the draft law on supported employment was submitted on 27 May 2019 by the Minister of Family, Labor, and Social Policy to the Government Legislation Center). It is a solution that will complement the existing solutions in the field of vocational rehabilitation in Poland and Greece. The idea 
of supported employment is based on an individualized process of getting a disabled person onto the labor market. It is also a form of cooperation with employers, labor market institutions, and the entities that perform tasks in the vocational and social rehabilitation of the disabled.

This review helps to understand the multifactored issue of sheltered employment in the concept of supported employment. The findings raise some critical issues that could puzzle the state authorities responsible for the active labor market policies, such as sheltered and supported employment. Additionally, the findings for the two European countries could raise awareness of the necessity of these policies on the vocational integration of people with disabilities.

In view of the above, both Poland and Greece need to have a clearer and more comprehensive legislative framework regarding supported employment. The two countries need to focus more on supported employment than on sheltered employment and adopt measures that will not only help to promote supported employment but also support the existing sheltered employment, from which better results are required. As Kober and Eggleton (2005, pp. 756-760) note, in terms of the social inclusion of people with disabilities in sheltered employment, the best outcomes can be achieved beyond the action of rehabilitation specialists through policies that will be followed at the governmental level.

\section{References}

Akkerman, A., Janssen, C.G.C., Kef, S., Meininger, H.P. (2016), Job satisfaction of people with intellectual disabilities in integrated and sheltered Employment: An exploration of the literature, "Journal of Policy and Practice in Intellectual Disabilities", 13 (3), pp. 205-216, https://doi.org/10.1111/jppi.12168

Barczyński, A. (2013), System wsparcia finansowego aktywizacji zawodowej osób niepełnosprawnych na otwartym i chronionym rynku pracy - ewolucja, stan i perspektywy, [in:] M.A. Paszkowicz, M. Garbat (eds.), Osoby z niepełnosprawnościami w polityce społecznej, t. 1: Praca zawodowa, Polskie Towarzystwo Ekonomiczne w Zielonej Górze, Zielona Góra, p. 63-78.

Barczyński, A. (2016), Skuteczność systemu zarządzania i aktywizacji zawodowej osób niepełnosprawnych, „Niepełnosprawność - Zagadnienia, Problemy, Rozwiązania”, IV (21), pp. 56-80.

Biuro Pełnomocnika Rządu do Spraw Osób Niepełnosprawnych (n.d.), http://www.nie pelnosprawni.gov.pl (accessed: 12.06.2020).

Burns, T., White, S.J., Catty, J. (2008), Individual placement and support in Europe: The EQOLISE trial, "International Review of Psychiatry", 20 (6), pp. 498-502, https:// doi.org/10.1080/09540260802564516

Cerebral Palsy Greece/Open Door (n.d.), https://www.eps-ath.gr/el/services/program mata-apasxolisis/paragogika-ergastiria.html (accessed: 18.02.2020). 
Cimera, R.E. (2017), The percentage of supported employees with significant disabilities who would earn more in sheltered workshops, "Research and Practice for Persons with Severe Disabilities”, 42 (2), pp. 108-120, https://doi.org/10.1177/154079 6917697448

Cimera, R.E., Wehman, P., West, M., Burgess, S. (2011), Do sheltered workshops enhance employment outcomes for adults with autism spectrum disorder?, "Autism", 16 (1), pp. 87-94, https://doi.org/10.1177/1362361311408129

Damon, J. (2012), Wykluczenie, Oficyna Naukowa, Warszawa.

Ebuenyi, I.D., Regeer, B.J., Nthenge, M., Nardodkar, R., Waltz, M., Bunders-Aelen, J.F.G. (2019), Legal and policy provisions for reasonable accommodation in employment of persons with mental disability in East Africa: A review, "International Journal of Law and Psychiatry", 64, pp. 99-105, https://doi.org/10.1016/j.ijlp.2019.02.007

European Commission (2021), Expenditure by LMP intervention - Greece (source: DG $E M P L)$, https://webgate.ec.europa.eu/empl/redisstat/databrowser/view/LMP_EXP $\mathrm{ME} \$ \mathrm{EL} /$ default/table?lang=en\&category=lmp_expend.lmp_expend_me (accessed: 12.07.2021).

Eurostat (2019), Self-perceived long-standing limitations in usual activities due to health problem by sex, age and income quintile, https:/ec.europa.eu/eurostat/databrowser /view/hlth_silc_12/default/bar?lang=en (accessed: 28.03.2021).

Garbat, M. (2013), European Policy Models of Employment of People with Disabilities, "Journal of Social Research \& Policy", 4 (1), pp. 47-63.

García-Villamisar, D., Wehman, P., Diaz Navarro, M. (2002), Changes in the quality of autistic people's life that work in supported and sheltered employment. A 5-year follow-up study, “Journal of Vocational Rehabilitation”, 17 (4), pp. 309-312.

Karakioulafi, C., Kanellopoulos, K., Petelczyc, J., Montgomery, T., Baglioni, S. (2020), Patterns of Labour Solidarity Towards Precarious Workers and the Unemployed in Critical Times in Greece, Poland, and the UK, "Sociological Research Online", https://doi.org/10.1177/1360780420980464

Kober, R., Eggleton, I.R.C. (2005), The effect of different types of employment on quality of life, "Journal of Intellectual Disability Research", 49 (10), pp. 756-760, https:// doi.org/10.1111/j.1365-2788.2005.00746.x

Lament, M. (2017), Quality of Non-Financial Information Reported by Financial Institutions. The Example of Poland and Greece, "Central European Review of Economics \& Finance”, 22 (6), pp. 5-16, https://doi.org/10.24136/ceref.2017.023

Metzel, D.S., Boeltzig, H., Butterworth, J., Sulewski, J.S., Gilmore, D.S. (2007), Achieving community membership through community rehabilitation provider services: Are we there yet?, "Intellectual and Developmental Disabilities", 45 (3), pp. 149-160, https://doi.org/10.1352/1934-9556(2007)45[149:ACMTCR]2.0.CO;2

Migliore, A., Grossi, T., Mank, D., Rogan, P. (2008), Why do adults with intellectual disabilities work in sheltered workshops?, "Journal of Vocational Rehabilitation", 28 (1), pp. 28-40.

National Confederation of Persons with Disabilities (NCDP) (2007), Access for people with disabilities to the world of work. Unemployment is the most severe form of social disability, https://www.esamea.gr/files/december/103/3rdDec_2007.pdf (accessed:

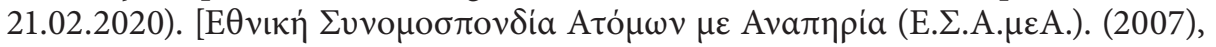




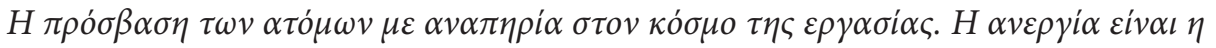

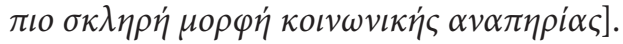

Osinska, M., Kluth, K. (2010), Convergence of Greek Economy with the EU and Some Comparisons with Polish Experience, "European Research Studies Journal", XIII (4), pp. 139-156, https://doi.org/10.35808/ersj/304

Paszkowicz, M. (2013), Zatrudnienie osób z niepełnosprawnościami: Ku otwartemu rynkowi pracy, [in:] M.A. Paszkowicz, M. Garbat (eds.), Osoby z niepetnosprawnościami w polityce społecznej, t. 1: Praca zawodowa, Polskie Towarzystwo Ekonomiczne w Zielonej Górze, Zielona Góra, pp. 37-62.

Stevens, P., Martin, N. (1999), Supporting Individuals with Intellectual Disability and Challenging Behaviour in Integrated Work Settings: An Overview and a Model for Service Provision, "Journal of Intellectual Disability Research", 43 (1), pp. 19-29, https://doi.org/10.1046/j.1365-2788.1999.43120169.x

Tsang, H.W.H., Chan, A., Wong, A., Liberman, R.P. (2009), Vocational outcomes of an integrated supported employment program for individuals with persistent and severe mental illness, "Journal of Behavior Therapy and Experimental Psychiatry", 40 (2), pp. 292-305, https://doi.org/10.1016/j.jbtep.2008.12.007

Vocational Rehabilitation Center for Persons with Disabilities (n.d.), http://www.kea -amea.gr/index.php/gr/ergasthria (accessed: 18.02.2020).

Wang, Y.-T., Lin, Y.-J., Shu, C.-H. (2012), Cost-benefit analysis for sheltered employment service programs for people with disabilities in Taiwan - a preliminary study, "Disability and Rehabilitation", 34 (19), pp. 1672-1676, https://doi.org/10.3109/096 38288.2012.656786

Wehman, P., Taylor, J., Brooke, V., Avellone, L., Whittenburg, H., Ham, W., Carr, S. (2018), Toward competitive employment for persons with intellectual and developmental disabilities: What progress have we made and where do we need to go, "Research and Practice for Persons with Severe Disabilities", 43 (3), pp. 131-144, https:// doi.org/10.1177/1540796918777730

\section{Acts of Law}

Act of 27 August 1997 on Vocational and Social Rehabilitation and Employment of Persons with Disabilities (Journal of Laws 2018, item 511) [in Polish].

Explanatory Report Law 4412/2016.

Law 2646/1998 "Development of the National Social Care System and other provisions”, OGG A” 236.

Law 4412/2016 "Public Works, Supplies and Services Contracts (Adaptation to Directives 2014/24/EU and 2014/25/ EU)", OGG A" 147.

L. 4413/2016 "Award and execution of concession contracts - Harmonization with European Directive 2014/23/EU of the European Parliament and of the Council of 26 February 2014 on the award of concession contracts (OJ L 94/1/28-3-14) and other provisions”, OGG A" 148.

Regulation of the Polish Minister of Labor and Social Policy of 19 December 2007 regarding the Company Fund for the Rehabilitation of the Disabled (Journal of Laws 2013, item 1300) [in Polish]. 


\section{Dylematy pracy chronionej w Polsce oraz Grecji a koncepcja zatrudnienia wspomaganego}

Osoby z poważnymi niepełnosprawnościami, takie jak upośledzenie umysłowe i zaburzenia ze spectrum autyzmu nie uczestniczą w otwartym, konkurencyjnym rynku pracy $w$ takim stopniu jak osoby pełnosprawne lub osoby $z$ innymi niepełnosprawnościami. Szansą dla tej grupy jest zatrudnienie chronione. To podejście do integracji zawodowej osób ze znacznym stopniem niepełnosprawności jest akceptowane na całym świecie. Jego realizacja odbywa się poprzez integrację osób niepełnosprawnych oraz stałe wsparcie: ze strony rządu lub samorządu. W artykule przedstawiono ramy prawne dotyczące zatrudnienia chronionego w Polsce i Grecji oraz sposoby jego realizacji wraz z odpowiednimi porównaniami i wnioskami. Wyniki wskazują na potrzebę bardziej precyzyjnych i kompleksowych ram prawnych dotyczących zatrudnienia chronionego w Polsce i Grecji. Tu na pierwszy plan wysuwają się alternatywne sposoby integracji zawodowej osób z poważnymi niepełnosprawnościami, takie jak programy zatrudnienia wspomaganego. Zatrudnienie wspomagane wydaje się jedynym, skutecznym i efektywnym sposobem na podjęcie pracy zarobkowej na równych zasadach przez osoby, które mają szczególne trudności w znalezieniu i utrzymaniu płatnej pracy na otwartym rynku pracy. Czy zatem koncepcja zatrudnienia wspomaganego ma szansę stać się komplementarnym narzędziem w aktywizacji zawodowej osób z niepełnosprawnościami w Polsce i Grecji? Z pewnością w obu krajach niezbędne są nie tylko stabilne źródła finansowania dla działań aktywizujących osoby z niepełnosprawnościami, ale również odpowiednie regulacje prawne oraz projekty systemowe.

Słowa kluczowe: zatrudnienie chronione, zatrudnienie wspomagane, niepełnosprawności, Polska, Grecja

\begin{tabular}{|l|l|}
\hline \multirow{2}{*}{ C. C) by the author, licensee Łódź University - tódź University Press, } \\
Łódź, Poland. This article is an open access article distributed under \\
the terms and conditions of the Creative Commons Attribution \\
license CC-BY-NC-ND 4.0 \\
(https://creativecommons.org/licenses/by-nc-nd/4.0/) \\
Received: 2020-09-07; verified: 2021-03-19. Accepted: 2021-05-21
\end{tabular}

